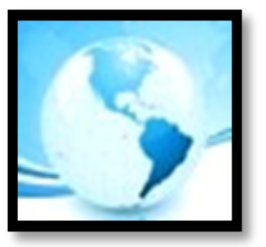

(MOJEM)

July 2018, VOLUME 6, ISSUE 3, 87 - 106

E-ISSN NO: $2289-4489$

https://doi.org/10.22452/mojem.vol6no3.5

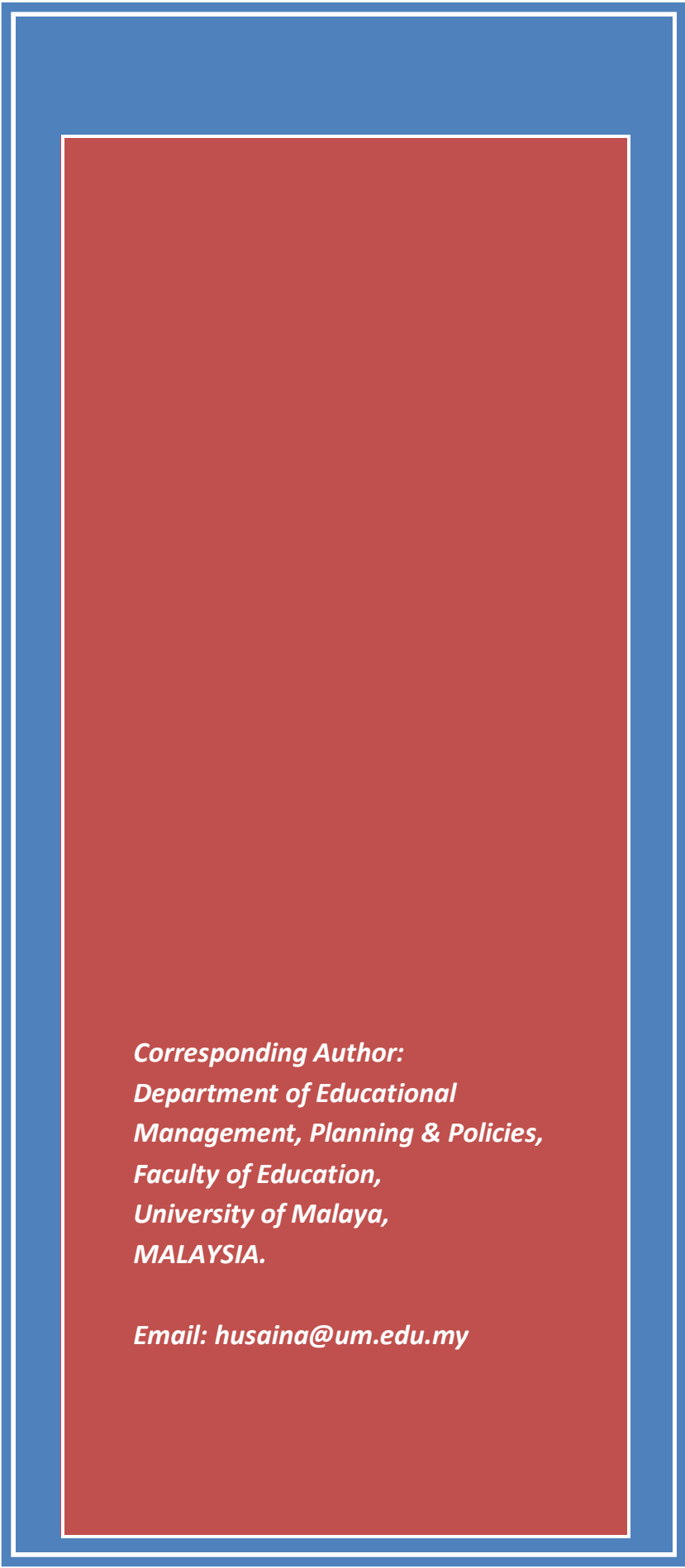

\title{
DETERMINANTS OF FINANCIAL ADEQUACY: EVIDENCE FROM MALAYSIAN TAMIL SCHOOLS
}

Husaina Banu Kenayathulla (PhD), Ranjeetham Subramaniam, Muhammad Faizal A. Ghani (PhD) \& Zuraidah Abdullah (PhD)

\begin{abstract}
Financial provision in education is one of the key factors contributing to the successful implementation of education programs in school. Financial management includes efficient management of school financial resources. However, the lack of financial resources affects students' achievement. Schools often encounter problems in providing the facilities needed by students. Schools receive financial resources in terms of per capita grants, public contributions and other government assisted funds such as scholarships and food supplements. The purpose of this study is to determine the adequacy of financial resources assigned to the National Type Tamil schools which are based on enrolment. This study was conducted in 30 National Type Government Tamil Schools and 16 National Type Government Assisted Tamil Schools in the State of Perak, Malaysia. A total of 276 respondents were involved in this survey. A logistic regression test was used to analyse factors contributing to the adequacy of financial provision for subjects, library, guidance and counselling and recurring expenditures. The findings indicate that policy makers should consider other factors such as socio-economic status and the type of schools in determining school funding allocation. Thus, the funding formula should not just be based on student enrolment.
\end{abstract}

Keywords: Adequacy, School Finance, Education, Malaysia. 


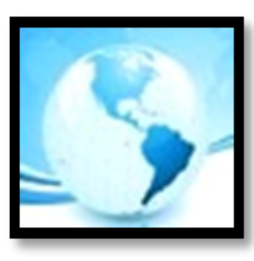

\section{MALAYSIAN ONLINE JOURNAL OF EDUCATIONAL MANAGEMENT (MOJEM)}

\section{INTRODUCTION}

School finance can be defined as a concept that involves management procedures that influence planning, administrating, instructing, and combining all the resources and segregation of duties and organisations based on the rules that have been predetermined (Baharin \& Abdul Kadir, 2013). School financial management aims at improving the situation of schools including teachers' performance, students' academic performance, social and physical environment of schools. Financial management should be handled systematically since it is very important and needed to be given attention to. This is because efficient financial management will ensure the highest return in education.

Financial management is an important component in any organization (Siraj et al., 2008). Financial management in government primary schools includes budget and expenditures, asset management, usage and acceptance of financial resources, budget and expenditures (Baharin \& Abdul Kadir, 2013).

According to Akmaliah (2001), the principal as the school administrator is fully responsible in ensuring efficient school financial management. Some of the school programs such as enrichment activities or remedial programs are not being conducted because of insufficient funding. But, whether the budget has been planned efficiently depends on the competency of school leaders in ensuring efficient resource allocation. For the highest returns to education principals should cut down wastage or resource misuse (Hussian \& Mohd Tahir, 2012).

Human capital development has been the priority of the Malaysian government. According to the Malaysian Ministry of Finance (2015), the government has allocated RM 56 billion for the education sector. Federal Budget allocation for education has increased from RM 29.3 billion in 2011 to RM50.2 billion in 2012. The annual budget for a school is allocated by the State Education Department or the Head of the Malaysian Ministry of Education. Educational expenditure increases annually due to two main factors. The first is the expansion of current policies, maintenance of expenditures, increase in expenditure due to inflation, equipment being disposed and increase in student enrolment. The second factor is the increase in educational needs motivated by development such as educational infrastructure and new policies.

Since independence, the Malaysian government has consistently allocated higher percentages of the budget to the education sector (Kenayathulla, 2014). Investment in human capital has been the Malaysian government priority. In order to achieve Vision 2020, Malaysia needs educated citizens who can contribute to the economy. According to the human capital theory, education equips an individual with knowledge and skills that enhances productivity.

An adequate educational budget is needed to ensure schools are able to implement various educational programs. However, the current funding mechanism is based according to the number of students, not based on school needs. According to the Financial Circular 8, school finance is allocated based on per capita grant and students' enrolment (MOE, 2012). Everyone regardless of ethnicity, gender and social class should be given equal opportunity in gaining quality education. An adequate budget is essential to ensure access to quality education.

In Malaysia, Tamil schools consist of National Tamil Schools and National Type Tamil Schools. Both schools are located in rural areas with lower number of students. These schools are given allocations based on per capita grant and number of students. Most of these children are from low income families. The government allocation is often inadequate to provide a convenient learning environment for the rural students. Additional enrichment and remedial activities was not able to be carried out due to insufficient funding. Inadequate school funding makes it difficult for the principal to manage school finances. 


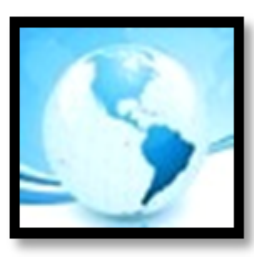

\section{MALAYSIAN ONLINE JOURNAL OF EDUCATIONAL MANAGEMENT (MOJEM)}

According to Ramloo (2000), in the research on school finance in Rawang, the school in the research encountered insufficient per capita allocation to support school expenditure. According to Mat Saad, Nik Yusoff and Mohammad Yassin (2011), financial allocation is needed to improve student performance. Additional funding is needed to improve and upgrade the learning facilities. Most of the primary schools in rural areas have fewer students compared to urban schools. This situation applies also to Tamil schools in rural areas. Primary schools in rural areas are also known as schools with fewer students (Abu Bakar \& Haji Buang, 2010).

Thus, the financial allocation provided by the government is according to the number of students in school. Additionally, the total allocation given to a school is based on the school size. Most of the Vernacular Tamil schools will receive less allocation since these schools have fewer students (Marzuki, 2005; Kenayathulla, 2015). This research aims at identifying factors that determine the adequacy of school finance in Tamil schools in Perak. The findings of this research are expected to provide insights to policy makers on the appropriate policy intervention needed to improve the adequacy of school finance especially in Tamil schools. This research also serves as guidance for other countries that has used the school funding formula.

\section{Educational Production Function}

The theoretical framework for this study is based on Education Production Function. Among the pioneer of Education Production Function, Hanushek (2010) described it as a function that analyses the relationship between inputs and outputs. In this context, education production function is usually used to determine the relationship between school level factors that determine students' performance. School level inputs can be class size, teacher quality, school resources such as library, computer, teaching and learning materials. The commonly used output is students' achievement (Pigott, Williams, Pollanin \& Wu-Bohanan, 2012). Financial allocation is one of the important inputs of education. Production function studies attempt to derive a model of the relation between educational inputs and outcomes. The goal of such studies is to develop quantitative models that allow one to predict the effect on student outcomes of a given change in resources. For example, a production function could predict how much the mean achievement on a standardized test would change if per pupil expenditures were increased by $\$ 100$. Similarly, it might enable identification of the most cost-effective means to improve public education (Hedges, Laine \& Greenwald, 1994).

\section{Financial Adequacy and Tamil Schools}

According to Kenayathulla (2015), Tamil schools encounter problems in managing school finance. The amount allocated is inadequate for preparing conducive teaching and learning environments. Most schools situated in the rubber estates and oil palm fields lack basic facilities such as a library, tables and chairs. Additionally, Ramloo (2000) noted that in a Tamil school in Rawang, the amount allocated by the government for annually recurring costs was insufficient for paying utility bills, telephone, student's transportation, printing and purchasing of teaching materials. This means the Tamil school principals need to find contribution from PIBG or other contributions to cover school related expenditures. Additionally, Tamil schools are not entitled for counselling teachers since the allocation of counselling teachers is based on school size. Thus, there are no facilities such as rooms, services or books for guidance and counselling (Ahmad, 2002).

\section{Financial Adequacy and Students Achievement}

Most Tamil schools are facing problems in terms of students' achievement due to the lack of learning facilities, school environment, and inability of students to master the Malay language alongside the lack of teachers. School environment, physical facilities, teachers and leadership becomes less of a motivating factor for students' performance in Tamil schools. 


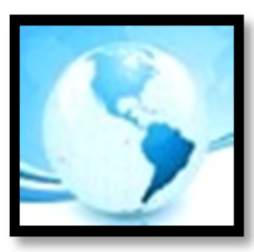

\section{MALAYSIAN ONLINE JOURNAL OF EDUCATIONAL MANAGEMENT (MOJEM)}

According to Mat Saad, Nik Yusoff and Mohammad Yassin (2011), the lack of learning facilities will hinder student performance. Lack of basic facilities results in lower performance of SJK Tamil school students compared to SJK Chinese school students (SJKC) and national schools (Rengasamy, 2007).

According to Mat Saad, Nik Yusoff and Mohammad Yassin (2011), the classroom environment plays an important role in providing a convenient and conducive learning environment. Small classrooms with overcrowded students and inadequate facilities make it difficult for the learning process (Mat Saad, Nik Yusoff, \& Mohammad Yassin, 2011; Tanner \& Lackney, 2006). According to Abu Bakar and Haridas (2011) in their research on National Type Tamil Schools which have fewer students in the district of Kota Tinggi, Johor, there are several factors influencing the gap in academic achievement. Among others are school infrastructure facilities, teaching and learning facilities, and the quality of teaching. Although there are enough teachers, the classroom size is not adequate for an effective teaching and learning process. Teachers will use laptops in class since there are no computers available in class. Additionally, the available resource centre is small. Thus, the library is used only for borrowing and reading books. Other activities could not be conducted because of lack of school funding (Abu Bakar \& Haridas, 2011). This shows that the National Type Tamil School still face problems in financial allocations.

Meanwhile, financial allocation also influences teacher professional development since it involves directly with student achievement. Previous studies consistently show effective teachers are important for students' achievement (Mat Saad, Nik Yusoff \& Mohammad Yassin (2011), According to Cooper and Schindler (2006), teachers should consistently improve knowledge and pedagogical skills from time to time through continuous professional development. Inadequate allocations result in continuous professional development conducted in schools by one of the school teacher based on prior knowledge they have. Thus, there is an inadequate financial allocation to hire experts to teach the relevant pedagogical and leadership related skills.

Financial inadequacy becomes one of the main contributors for the achievement gap for SJK Tamil. Inadequate financial allocation results in inability of the school principals to prepare the facilities at the school level to improve the performance of students. The school administrator is not able to prepare facilities that are needed by the school to increase students' achievement. Students in urban areas are able to perform compared to students in rural areas due to better facilities and learning resources (Yee, 2005; Marzuki, 2008). In addition, schools in rural areas encounter inadequate resources in terms of equipment, basic facilities, infrastructure, teachers and parental support (Siraj et al., 2008).

There are also socio-economic differences between students in urban and rural areas. According to Kling et al. (2007), most students are from lower socio-economic background and those who are residing in rural areas perform less than those in urban areas. According to Ramloo (2000), most parents that send their kids to Tamil school are from middle and lower socio-economic group. Research consistently showed that students from higher socio-economic background have positive impact on students' performance (Johari, 2002).

\section{Issues in the School Financial Management}

Most Tamil schools in Malaysia are non-responsibility centre management schools. Thus, these schools do not have autonomy in determining the school expenditure. Additionally, most parents in these schools are from lower socio-economic background and work as rubber tappers, thus they are not able to provide additional funding for the schools (Nor Eazrin, 2004; Subathirah, 2000). Adequate financial allocation becomes an important factor that determines students' achievement in SJK Tamil. According to Rawls's fair equality of opportunity, any policies that help to reduce the economic burden of schooling for households with lesser means, including provision of a more conductive learning environment for children in need are acceptable. 


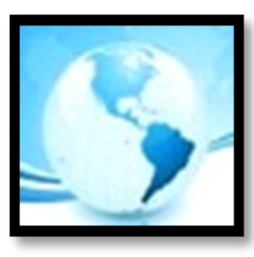

\section{MALAYSIAN ONLINE JOURNAL OF EDUCATIONAL MANAGEMENT (MOJEM)}

\section{Sources of School Finance}

Financial allocation can be defined as the money that is spent to get other materials such as physical source, human and time, teacher's teaching materials, physical resource for building, materials, books and any programs for professional development of teachers (Anderson et al., 2001).

Malaysian government provides per capita grant for academic subjects and non-academic subjects. According to Abu Bakar (2010), school has three main sources of funding such as SUWA (public donation) fund, government funding, and residential funding. Financial Circular No. 8 explained that funding will be provided by the Malaysian government for operational expenditures for both government school and government aided schools (MOE, 2012). School related expenditures are provided to ensure effective implementation of the programs (Abu Bakar, 2010). All Tamil schools will receive per capita funding from the government. Additional contribution usually comes from Parents and Teachers Associations (MOE, 2012).

\section{Financial Management in Developed and Developing Nation}

Financial management influences overall school management. According to Vasquez, Williams, and Jez (2010), sources of finance determines the success and students' achievement. Both developing and developed countries have their own financial management system. The amount of fund allocated for educational expenditures depend on each country.

According to Johnstone (2004), cost sharing for education is a way of transferring the responsibility from the government to parents. Cost sharing has been the trend in many European countries. Government has introduced educational fees, food expenses and accommodation and scholarships for students. In developed countries, state level government and local government also plays an important role in financing education. Bruce and David (2002) stated that sources of educational funding in the USA are mainly from state and local government but half of the funding comes from local tax. The disparities in educational funding across states and local government resulted in differences in the quality of school buildings and other infrastructure facilities. According to Heather Rose and Margaret (2013), in Western California, the disadvantaged students from lower socio-economic status received about 36 percent more educational allocations than others. Thus, the transition that occurred in school finance from equity to adequacy ensures that students receive adequate level of education.

In Australia, since 2009, the government funding for schools is provided under the national school's specific purpose payment (National Schools SPP), which has two components, one for government schools and one for non-government schools. Additional funding is also provided through National Partnerships (NPs) and annual appropriations (Harrington, 2011).

In Sweden, all the education in the public-school system is free of charge for pupils and is funded entirely by the public authorities. Funding is provided through resources contributed by municipalities out of local tax revenues plus a general government grant to municipalities, which is linked to a special equalization system intended to create equal financial conditions for all municipalities and country councils. This is to ensure that all municipalities are able to deliver equal levels of service irrespective of the income of the residents. Income equalization and cost equalization are two of the methods commonly used to equalize the disparities across municipalities. The income equalization grant is calculated on the basis of the differences between taxable income and tax equalization base. Municipalities whose taxable income exceeds the tax equalization base will pay a fee. On the other hand, municipalities whose taxable income is less than the tax equalization base will receive a grant. The same principal applies to equalization of cost. Those municipalities with a less advantaged cost structure will receive a grant from the state and those having a favourable cost structure will pay a charge to the state. 


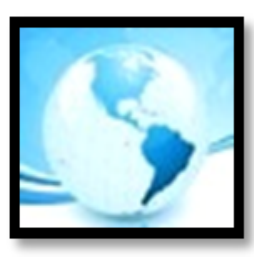

\section{MALAYSIAN ONLINE JOURNAL OF EDUCATIONAL MANAGEMENT (MOJEM)}

Schools might cost more in rural areas since there are higher percentages of students with a foreign background. Additionally, targeted grants are also provided by the state government (Sweden Ministry of Education and Research, 2008).

The need to upgrade the educational quality becomes the big challenge for policy makers in developing countries where education takes a large portion of the government budget. The focus of many developing countries is to overcome equity issues in educational funding (Kenayathulla \& Ibrahim, 2013). In developed countries, the government is able to fully fund education due to strong economic growth. In Indonesia, the state and district have problems such as limited funding, lack of infrastructure and lack of text books (Ahmad et al., 2013).

\section{School Financial Management in Malaysia}

Financial management is a process where financial allocation is managed by the government through certain approaches where sources of public funding are obtained, spent and accounted. The Malaysian federal government has been the main financier for education in Malaysia. The federal government allocates a substantial amount of money for education ranging from $8 \%$ to $30 \%$ from the total federal allocations. However, the local and state government did not play the main role in financing education (A. Ghani et al., 2013). The Malaysian government emphasizes on educational investments since human capital development is a key factor for economic growth (Siraj et al., 2008). Education helps to develop and enhance the needed skills for the workforce (Marzuki, 2005).

The school funding formula in Malaysia is based on the number of students and this is consistent with other countries in the world (Marzuki, 2005). Per capita grant is provided for academic subjects and non-academic such as library, guidance and counselling services. Additionally, poor students are also entitled for food supplementary programmes and KWAMP (Trust fund for students from lower income families). The purpose of KWAMP is to reduce the burden of lower income families for educational related expenses for their children and also to encourage parents to send their children to school. In addition, there are one-off payments amount up to RM200 for poor students to purchase uniforms and school supplies (MOE, 2013). However, such allocation is not enough to accommodate the needs of less fortunate students.

In Malaysia, the principal are responsible in planning, monitoring and making adjustments on school finance. The principals are responsible for handling and managing money based on their experience and are assisted by the financial clerks. The budget will be prepared by the principal to ensure effective school financial management (Marzuki, 2005). There are two types of schools in Malaysia: responsibility centre and non-responsibility centre schools. Principals in responsibility centre schools have more freedom to finance the budget. Financial management of school should follow the educational regulations 2002 under the Education Act 1996. According to the circular, schools should prepare financial statements not later than 31 March every year. According to the financial circular, Ministry of Education No. 4. (1988), schools should submit their financial statements earlier on 28/29 February to ensure adjustments can be made and the principal can manage the school finances to be consistent with the guidelines stated in the financial guidelines of the school, treasury directions and circular distributed to financial division, education ministry and state education department.

Other than the Ministry of Education, the Parent Teacher Association (PTA) and Non-governmental organizations (NGOs) also play an important role in school finance. The PIBG plays a greater role in school finance. PIBG will discuss with the school regarding the appropriate activities to raise fund for the schools (Mohamed, 2010). 


\section{RESEARCH METHODOLOGY}

\section{Research Design}

Research design involves planning on how the study will be carried out and data will be collected (Bogdan \& Biklen, 2003; Copper \& Schindler, 2006). Research design is important to ensure the research can be conducted smoothly and findings can be presented in order. In this study, quantitative research was applied and questionnaires were distributed. Quantitative research design is appropriate when the analysis requires response from larger sample (Idris, 2010).

\section{Population and Sampling}

The population for this study consisted of National Type Tamil schools and government-aided National Type Tamil schools in Perak, a total of 696 respondents. The samples were chosen from school management teams comprising of headmasters, deputy headmasters for academic, student affairs and co-curriculum and heads for subjects. These samples were management teams who are directly involved in the management of school finance. The chosen samples was adequate to represent the population. Uma (2003) noted that the sample size which is between 30-500 people is enough for exploratory research. Minimum sample that has been suggested by Krejcie and Morgan (1970) is 269. The researcher has distributed 276 questionnaires to ensure that the total sample fulfil the needs of the research and that the sample that is chosen is bigger than the sample suggested by Krejcie and Morgan (1970).

Table 1

Population and sample of the research

\begin{tabular}{lcc}
\multicolumn{1}{c}{$\begin{array}{c}\text { Schools according to } \\
\text { region in Perak }\end{array}$} & Population size & Sample size \\
\hline Hulu Perak & 47 & 18 \\
Larut Matang Selama & 80 & 30 \\
Hilir Perak & 65 & 30 \\
Kuala Kangsar & 74 & 30 \\
Kerian & 55 & 30 \\
Manjung & 85 & 30 \\
Batang Padang & 70 & 30 \\
Perak Tengah & 33 & 18 \\
Kinta Utara & 98 & 30 \\
Kinta Selatan & 72 & 30 \\
\hline \multicolumn{1}{c}{ Total } & 679 & 276 \\
\hline
\end{tabular}

Source: Malaysian Ministry of Education, 2015.

In this context, stratified sampling has been used to select the samples. Five schools were chosen from each district except for District of Hulu Perak and Perak Tengah since these districts only have three Tamil schools. From each school, six senior management staff were chosen totalling to 276 samples from all the schools selected. 


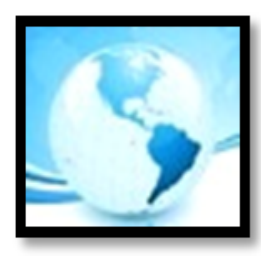

Table 2

Number of Fully aided National Type Tamil Schools and partially aided National Type Tamil Schools for every district.

\begin{tabular}{lcccc}
\hline \multicolumn{1}{c}{ Districts } & $\begin{array}{c}\text { Total SJK(T) in each } \\
\text { district }\end{array}$ & \multicolumn{2}{c}{ Total school involved in the sample } & Total \\
\cline { 3 - 5 } & & SJK(T) partially aided & $\begin{array}{c}\text { SJK(T) } \\
\text { government }\end{array}$ \\
\hline Kuala Kangsar & 12 & 4 & 1 & $5(41.6 \%)$ \\
Kerian & 14 & 3 & 2 & $5(35.7 \%)$ \\
Manjung & 15 & 3 & 2 & $5(33.3 \%)$ \\
Batang Padang & 19 & 3 & 2 & $5(26.3 \%)$ \\
Perak Tengah & 3 & 3 & - & $3(100 \%)$ \\
Kinta Utara & 14 & 3 & 2 & $5(35.7 \%)$ \\
Kinta Selatan & 9 & 3 & 2 & $5(55.5 \%)$ \\
Hilir Perak & 28 & 2 & 1 & $5(17.8 \%)$ \\
Hulu Perak & 3 & 3 & 2 & $3(100 \%)$ \\
Larut Matang Selama & 17 & & $5(29.4 \%)$ \\
\multicolumn{1}{c}{ Total } & & 30 & 16 & $46(34.3 \%)$ \\
\hline
\end{tabular}

\section{Instruments}

Questionnaires are a commonly used method to get a response from wider participants. According to Mat Talib et al. (2011), formal questionnaire is a tool used to obtain information directly from the respondent on the matter studied by the researcher. Quantitative data can be viewed as public opinion, as well as the impact of the system being used. Apart from that, the presented questions must be direct. If not, it leads to multiple answers and makes it difficult to analyse (Hassan \& Arifin, 2011).

The questionnaire items were developed based on the school audit report, Financial Circular 2012, National Educational Blueprint 2013-2025 and the module and school financial management notes. There are 7 sections in the questionnaires: Section A consisted of 8 items on the demographic information of the respondents. Section B consisted of 13 items on the demographic information of the school. Section C consisted of 18 items on the financial allocation given to schools. Section D consisted of 14 items on the financial adequacy for school infrastructure and activities. Section E consisted of 18 items on the impact of inadequate funding on teaching and learning. Section $\mathrm{F}$ consisted of 12 items on the financial management knowledge among the senior management team. Section $\mathrm{G}$ consisted of 21 items on the challenges faced in the financial management and lastly Section $\mathrm{H}$ consisted of 14 strategies to overcome the financial management issues.

For section A and B, the questions were in terms of check list, semi-structured and open ended. For Section C, D, E and $G, 5$ points Likert scale has been used in the questionnaires: Strongly agree, agree, quite agree, disagree, and strongly disagree. For Section F: the 5 points Likert scale consisted of highly competent, moderate competent, lack of competency, not competent, highly not competent. 


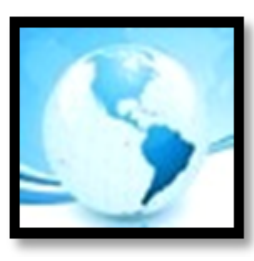

\section{MALAYSIAN ONLINE JOURNAL OF EDUCATIONAL MANAGEMENT (MOJEM)}

\section{Validity and Reliability}

The questionnaires were validated by two content experts in the field of school finance. To ensure its reliability for use with the sample, a pilot study was tested among 30 senior management staff of the school. The questionnaire used in this research is reliable in the sense that the results will be replicable when the research would be conducted again with the similar sample, keeping in mind that all the factors have to be kept the same. In this research, the reliability was tested by using SPSS version 20. The Cronbach alpha for all the items is more than 0.7 . Thus, the instrument is proven to be reliable.

\section{Data Analysis}

Data for this study has been analysed using descriptive statistics such as mean and standard deviation. Additionally, inferential statistics such as binary logistic regression was used to determine the factors that contribute to financial adequacy. According to Palaniappan (2007), SPSS is a powerful data analysis software that is easy to use, especially for the social sciences. The software is not only used in the field of education but also used in business and medicine.

\section{Descriptive Statistics and Inferential Statistics}

Creswell (2005) stated that descriptive statistics were used to answer when research questions require seeing the difference between variables and the relationships between variables. The descriptive analysis using frequency, percentage, mean and standard is deviation suitable for researchers to get a more extensive and comprehensive, detailed and accurate analysis as required in the research objectives. According to Pallant (2001), the survey must correspond to the study objectives in order to be more accurate, comprehensive and meaningful. Inferential statistics is used to describe the relationship between variables. It is used to describe the characteristic of the chosen sample. The sample must represent the population. Logistic regression analysis is used to analyse the relationship between binary or dichotomic variables (Hosmer \& Lemeshow, 1989). Binary variables have only two responses $(Y=1)$ or $(Y=0)$. According to Hosmer, Lemeshow, and Sturdivant (2013), logistic regression is used when the dependent variables are dichotomy variables. This means when the dependent variable has two values $(Y=1)$ or $(Y=0)$. Unlike ordinary regression analysis, logistic regression did not assume linear relationship between dependent and independent variables (Hosmer et al., 2013).

In this research, researchers were able to determine whether GPS, UPSR, average family income, number of teachers, students, and school financial staff, school location, number of students, and type of school which influenced the adequacy of financial allocation for Tamil schools. The dependent variables in research are dichotomy variables that are whether financial allocation is adequate $(Y=1)$ or not adequate for financial allocation in Tamil schools $(\mathrm{Y}=0)$.

$$
\begin{aligned}
& \text { Adequacy of allocation }=\underline{\ln [\text { Probability (adequate)] }} \\
& =b_{0}+b_{1} X_{1}+b_{2} X_{2}+b_{3} X_{3}+b_{4} X_{4}+b_{5} X_{5}
\end{aligned}
$$

When, $b 0$ is a constant logistic regression and $b 1, b 2, b 3, b 4, b 5$ are logistic coefficient for every predictor variable. 


\section{FINDINGS AND DISCUSSIONS}

A total of 318 questionnaires were distributed to 46 Tamil schools in Perak with only 276 questionnaires were returned representing $86.79 \%$ response. Meanwhile, 42 questionnaires were not returned (13.20\%). Therefore, 276 respondents were involved in this study $(\alpha=276)$. The study involved 70 male respondents $(25.4 \%)$ and 206 female respondents (74.6\%). According to Table 3, most of the respondents (46 percent) were between 25 to 35 years.

Table 3

Age of respondents

\begin{tabular}{lcc}
\hline Age & Mode & Percentage \% \\
\hline $25-35$ years & 127 & 46.0 \\
$36-45$ years & 74 & 26.8 \\
$46-56$ years & 66 & 23.9 \\
Over 56 years & 9 & 3.3 \\
\hline Total & 276 & 100.0 \\
\hline
\end{tabular}

Table 4

School Location

\begin{tabular}{lcc}
\hline Location of School & Mode & Percentage (\%) \\
\hline Urban areas & 8 & 17.4 \\
Rural areas & 38 & 82.6 \\
\hline Total & 46 & 100.0 \\
\hline
\end{tabular}

Table 4 showed that the majority of the schools involved in this study were located in rural areas (82.6 percent) while 17.4 percent were located in urban areas. According to Table 5, 65.2\% of the schools were partially aided schools. Meanwhile, 16 schools were fully aided national type Tamil schools (34.8\%). Band is the ranking used to indicate student performance. According to Table 5, result of the study shows that 32 of 46 schools (69.6 percent) involved in this study were ranked Band 3. Meanwhile, another 12 schools ranked Band 2 (26.1\%) and only 2 schools were ranked Band 3 (4.3\%).

Table 5

School Ranking

\begin{tabular}{lcc}
\hline Ranking of school & Mode & Percentage (\%) \\
\hline Band 1 & 0 & 0 \\
Band 2 & 12 & 26.1 \\
Band 3 & 32 & 69.6 \\
Band 4 & 2 & 4.3 \\
Band 5 & 0 & 0 \\
Band 6 & 0 & 0 \\
\hline Total & 46 & 100.0 \\
\hline
\end{tabular}




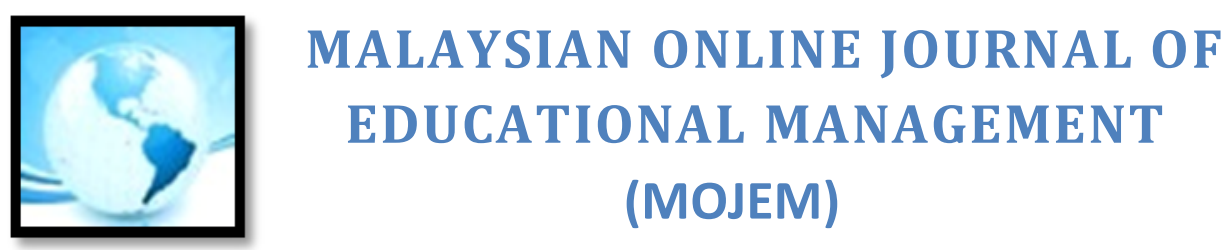

\section{Primary School Achievement Test (UPSR)}

One of factors affecting the ranking of schools is the students' academic achievement. Average School Grade (GPS) (UPSR) 2014 was used as the factor for school ranking. In Table 6, 38 schools (about 82.6 percent) achieved GPS UPSR at the range of 2.01 to 3.00. Meanwhile, 4 schools reached GPS UPSR between 3.01 to 4.00 and 1.00 to 2.00 respectively. This amount represents $8.7 \%$ of total. However, there is no school at the range of 4.01 to 5.00 for GPS UPSR.

Table 6

GPS UPSR 2014

\begin{tabular}{lcc}
\hline GPS UPSR & Mode & Percentage (\%) \\
\hline $4.01-5.00$ & 0 & 0 \\
$3.01-4.00$ & 4 & 8.7 \\
$2.01-3.00$ & 38 & 82.6 \\
$1.00-2.00$ & 4 & 8.7 \\
\hline Total & 46 & 100.0 \\
\hline
\end{tabular}

The numbers of students and teachers are important elements in school financial management as they contribute to the allocation of the school budget because the allocation received by the school is based on number of students who takes subjects or per capita grant (PCG) and the program carried out. This means that the greater the number of students, the greater the amount of allowance granted to the schools. This allocation provides an opportunity for schools to implement more school activities to benefit students. However, most of the Tamil schools involved in this study have a student population of less than 500 pupils.

Table 7

Number of students

\begin{tabular}{lcc}
\hline Number of students & Mode & Percentage (\%) \\
\hline less 20 pupils & 7 & 15.2 \\
$20-50$ pupils & 16 & 34.8 \\
$50-100$ pupils & 10 & 21.7 \\
$100-150$ pupils & 6 & 10.9 \\
$200-300$ pupils & 4 & 8.7 \\
$400-500$ pupils & 2 & 4.3 \\
more 500 pupils & 2 & 4.3 \\
\hline Total & 46 & 100.0 \\
\hline
\end{tabular}

Based on Table 7, 16 schools have between 20 to 50 pupils (34.8\%). Meanwhile 10 schools have between 50 to 100 pupils (21.7\%) and 7 schools have less than 20 pupils (15.2\%). However, 6 schools have from 100 to 150 pupils (10.9\%). Furthermore, 4 schools have between 200 to 300 pupils and 2 schools have between 400 to 500 pupils and more than 500 pupils respectively. This represents $8.7 \%$ and $4.3 \%$ respectively. 


\section{The Average Family Income}

Table 8 showed an average family income for students at the schools involved. In this study, most of the students are from lower socio-economic backgrounds since the average family income is RM1000 and below.

Table 8

Average family income

\begin{tabular}{|c|c|c|}
\hline $\begin{array}{l}\text { Average income } \\
\text { (RM) }\end{array}$ & Mode & Percentage (\%) \\
\hline less 400 & 4 & 8.7 \\
\hline $401-500$ & 9 & 19.6 \\
\hline $501-600$ & 11 & 23.9 \\
\hline $700-1,000$ & 21 & 45.7 \\
\hline More than ,1500 & 1 & 2.2 \\
\hline Total & 46 & 100.0 \\
\hline
\end{tabular}

\section{Number of Teachers and Staff}

The number of staff and teachers also impact the school's financial management. The more numbers of staff and teachers in a particular school, the more budget will be allocated to those schools in terms of emolument such as wages and allowance, claim, bonus and so forth. Table 9 showed the number of teachers in the sampled schools. About $78.3 \%$ of the sampled schools have about $10-20$ teachers.

Table 9

Number of teachers in sampled schools

\begin{tabular}{lcc}
\hline Number of teachers & Number of schools & Percentage (\%) \\
\hline Less than 10 teachers & 4 & 8.7 \\
$10-20$ teachers & 36 & 78.3 \\
$21-30$ teachers & 3 & 6.5 \\
$31-40$ teachers & 2 & 4.3 \\
More than 40 teachers & 1 & 2.2 \\
\hline Total & 46 & 100.0 \\
\hline
\end{tabular}

\section{The Number of Support Staff to Assist in the School Financial Management}

Support staff is needed for teachers to manage the school finances efficiently and effectively. However, the numbers of support staff in the school who help to manage school funding are still insufficient and unskilled.

According to Table 10, two schools have a chief administrative assistant. Meanwhile, all Tamil schools involved in this study only have an administrative assistant who was able to manage the financial of their school. There are 28 schools with Lower General Assistants but unfortunately, the schools with lower number of students was not entitled for such positions. 


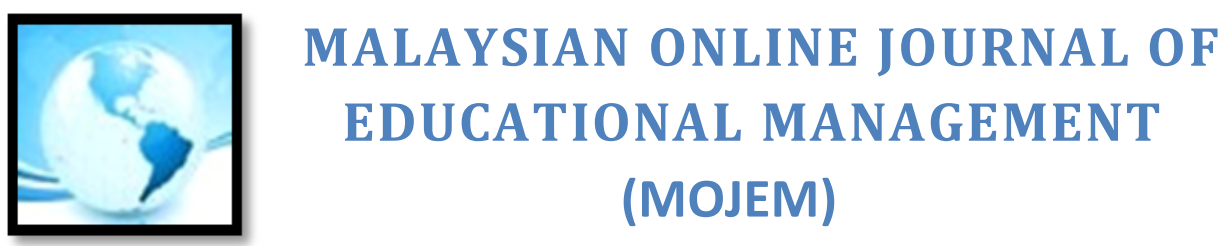

Table 10

The number of support staff to assist in the financial management at school

\begin{tabular}{lcc}
\hline Position & Grade & Number \\
\hline Chief Administrative Assistant & N22 & 2 \\
Administrative Assistant & N17 & 46 \\
Lower general assistant & N1 & 28 \\
\hline
\end{tabular}

\section{Factors Contributing To the Adequacy of the Financial Provision for National Type Tamil Schools in Perak}

This part of the analysis concentrates on the factors that contribute to the adequacy of school finance in Perak. In this analysis, logistic regression was used to identify factors that determine financial adequacy. The dependent variable was dichotomous (binary). Table 11 showed the variables and categories.

Table 11

Variables and categories

\begin{tabular}{|c|c|c|}
\hline Variables & Data Category & Data Category \\
\hline $\begin{array}{l}\text { Dependent Variable: } \\
\text { Adequacy of provisions }\end{array}$ & Yes=1 & $\mathrm{No}=0$ \\
\hline \multicolumn{3}{|l|}{ Independent Variable: } \\
\hline $\begin{array}{l}\text { UPSR (GPS 2014) } \\
(1.00-3.00)\end{array}$ & $\begin{aligned} \text { Yes }= & \text { UPSR }(\text { GPS 2014) } \\
& (1.00-3.00)\end{aligned}$ & $\begin{aligned} \mathrm{No}= & \text { UPSR (GPS 2014) } \\
& (4.00-5.00)\end{aligned}$ \\
\hline $\begin{array}{l}\text { Ranking of School } \\
(4-6)\end{array}$ & $\begin{array}{l}\text { Yes }=\text { Ranking of School } \\
\qquad(4-6)\end{array}$ & $\begin{array}{l}\text { No= Ranking of School } \\
\qquad(1-3)\end{array}$ \\
\hline $\begin{array}{l}\text { Number of students } \\
(200->500)\end{array}$ & $\begin{array}{c}\text { Yes }=\text { Number of students } \\
(200-500)\end{array}$ & 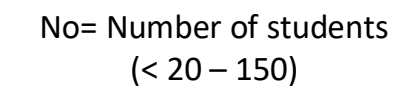 \\
\hline $\begin{array}{l}\text { Average Family Income (RM } 700 \text { - > } \\
\text { RM1500) }\end{array}$ & $\begin{array}{l}\text { Yes= Average Family Income } \\
\quad \text { (RM } 700->\text { RM1500) }\end{array}$ & $\begin{aligned} \text { No }= & \text { Average Family Income } \\
& (<\text { RM 400-RM600) }\end{aligned}$ \\
\hline $\begin{array}{l}\text { Number of Teachers } \\
(21->40)\end{array}$ & $\begin{array}{c}\text { Yes }=\text { Number of Teachers } \\
\qquad(21->40)\end{array}$ & $\begin{array}{c}\text { No= Number of Teachers } \\
\qquad(<10-20)\end{array}$ \\
\hline $\begin{array}{l}\text { Number of Staff } \\
(3-4)\end{array}$ & $\begin{array}{c}\text { Yes=Number of Staff } \\
(3-4)\end{array}$ & $\begin{array}{c}\text { No }=\text { Number of Staff } \\
(1-2)\end{array}$ \\
\hline Urban areas & Yes $=$ urban area & $\mathrm{No}=$ rural area \\
\hline Public school & Yes=Public School & No $=$ Govt-Aided school \\
\hline
\end{tabular}




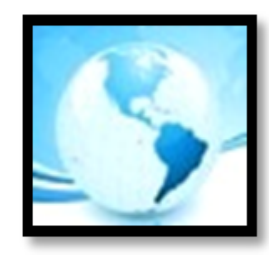

Table 12

Logistic regression for the adequacy of provisions for the subject, counselling, Library and recurring expenditures

\begin{tabular}{|c|c|c|c|c|}
\hline Variables & $\begin{array}{l}\text { Coef./SE } \\
\text { Subjects }\end{array}$ & $\begin{array}{c}\text { Coef./SE } \\
\text { Counselling }\end{array}$ & $\begin{array}{c}\text { Coef./SE } \\
\text { Library }\end{array}$ & $\begin{array}{c}\text { Coef./SE } \\
\text { LPBT }\end{array}$ \\
\hline UPSR (GPS 2014) & $0.191^{* *}$ & 0.028 & $0.182^{* *}$ & $0.275^{* *}$ \\
\hline$(1.00-3.00)$ & 0.083 & 0.146 & 0.070 & 0.112 \\
\hline Ranking of school ${ }^{1}$ & -0.084 & 0.253 & -0.162 & 0.109 \\
\hline$(4-6)$ & 0.216 & 0.218 & 0.148 & 0.254 \\
\hline Number of students & 0.169 & $-0.215^{* *}$ & 0.239 & 0.114 \\
\hline$(200->500)$ & 0.131 & 0.085 & 0.163 & 0.147 \\
\hline Average family income & $-0.150 * *$ & 0.083 & $-0.102 * *$ & -0.023 \\
\hline (RM 700 - > RM1500) & 0.072 & 0.076 & 0.069 & 0.080 \\
\hline Number of Teachers & 0.151 & $0.835^{* *}$ & -0.054 & $0.437^{* *}$ \\
\hline$(21->40)$ & 0.134 & 0.034 & 0.113 & 0.094 \\
\hline \multirow{2}{*}{$\begin{array}{l}\text { Number of staff } \\
(3-4)\end{array}$} & 0.058 & 0.034 & 0.143 & 0.141 \\
\hline & 0.090 & 0.092 & 0.092 & 0.092 \\
\hline \multirow[t]{2}{*}{ Urban area } & -0.055 & 0.174 & 0.062 & 0.138 \\
\hline & 0.097 & 0.090 & 0.080 & 0.106 \\
\hline \multirow[t]{2}{*}{ Public school } & -0.132 & -0.137 & -0.069 & $0.080^{* *}$ \\
\hline & 0.074 & 0.081 & 0.066 & 0.080 \\
\hline
\end{tabular}

$\left({ }^{*}\right) \mathrm{die} / \mathrm{dx}$ is the discrete changes in dummy variable $0-1$

** Significant at the 5 percent

Table 12 showed the determinants of financial adequacy for subjects, counselling, library and recurring services. In the first column, the marginal effect for UPSR is positive and significant. The results showed that the schools with a lower UPSR GPS (1.00 to 3.00) were 19 percent more likely to have financial adequacy in the allocation for subjects compared to schools with higher UPSR GPS, holding other variables constant.

The coefficient for schools with a higher average family income (RM700 to RM 1500) was negative and statistically significant. This showed that schools with a higher average family income were 14 percent less likely to have financial adequacy for subjects compared to schools with lower average family income, holding another variables constant. The study also revealed other factors such as school rankings; number of students, teachers, staff, school location and type of school were not statistically significant. The results indicated that these factors were not important determinants of financial adequacy for subjects.

The second column showed the financial adequacy for counselling subjects and its results showed that the coefficient for greater number of students is negative and statistically significant. The findings showed that schools with greater number of students (200 to 500) were 22 percent less likely to have financial adequacy in counselling than schools with less students. 


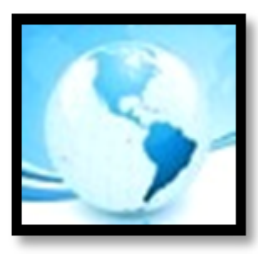

\section{MALAYSIAN ONLINE JOURNAL OF EDUCATIONAL MANAGEMENT (MOJEM)}

Meanwhile, the schools with the highest number of teachers (21 to 40) were more likely to have financial adequacy in guidance and counselling compared to schools with less teachers, holding other variables constant. The findings also indicated that other factors such as GPS UPSR 2014, ranking school, family income, staff, location of school and type of schools are not significant. Thus, these factors were not determinants of financial adequacy for counselling.

The third column shows the financial adequacy for library and resources. The results showed that the schools with lower UPSR GPS (1.00 to 3.00) were 18 percent more likely to have financial adequacy for a library than schools with higher UPSR GPS. Meanwhile, the school with a higher average family income (RM700 to RM 1500) is 10 per cent more likely to have financial adequacy for library and resources than schools with a lower average family income. The findings also revealed that other factors such as the ranking, number of students, teachers and staff, school location and type of school are not significant. Thus, these factors do not affect the adequacy of financial provision for library and counselling.

The fourth column showed the financial adequacy for recurring expenditures. The results show that the schools with lower GPS UPSR (1.00 to 3.00) were 27 percent more likely to have financial adequacy for recurring expenditures compared to schools with higher GPS UPSR. Meanwhile, schools with greater number of teachers ( 21 to 40) were 44 percent more likely to have financial adequacy for recurring expenditures compared to schools with lower number of teachers, holding another variables constant. In addition, fully funded national type Tamil schools are 7 percent more likely to have financial adequacy for LPBT compared to partially funded Tamil schools. The study also revealed that other factors such as schools ranking, number of students, staff, location and family income are not statistically significant. Thus, these factors do not affect the financial adequacy of other recurring expenditures.

Overall findings indicated that GPS for UPSR is an important determinant of financial adequacy for subjects, library, and recurring expenditures. Higher performing schools (lower GPS score) usually consisted of students who are financially better than lower performing schools (Higher GPS UPSR score). Thus, the parents are able to financially support for a better learning environment. Previous study indicated that Tamil schools have limited space for library. Thus, students only use library to borrow books and any programmes cannot be conducted in the library due to limited space. Some of these schools are also lacking in terms of basic facilities such as library, tables and chairs (Abu Bakar \& Haridas, 2011, Kenayathulla, 2015). The findings also indicated that average family income is an important determinant of financial adequacy for subjects and library. According to Parcel \& Dufur (2001), higher income parents are able to help students in terms of financial and social capital to ensure students perform better.

The results also showed that number of students is an important determinant of financial adequacy for counselling. Students need advice to solve their problems, either through personal or group discussions with the counsellor. The counsellor will discuss with the students to determine the best approach to solve the problems (Ahmad, 2002). However, schools that have lesser number of students are not allocated budget for a counsellor. The number of teachers is an important determinant of financial adequacy for counselling and other recurring expenditures.

Fully funded or partially funded Tamil schools also determine the financial adequacy for recurring expenditures. According to Subathirah Ramloo (2000), financial allocation for Tamil schools are inadequate in terms of the payment of utility bills, purchasing of school's equipment and teaching aids. Contribution from Parents Teachers Association plays an important role in determining the adequacy of school funding. 


\section{IMPLICATIONS AND CONCLUSION}

Currently, the funding formula for school finance in Malaysia is based on the number of students. Indeed, the findings consistently show that the number of students is an important factor that determines financial adequacy. Results also indicate that other factors needed to be considered in determining financial adequacy. The findings suggested that the average family income is an important determinant of financial adequacy for academic subjects and library facilities. Thus, the schools with higher percentage of lower socio-economic students should be given extra funding so that the library facilities can be upgraded. Most often, the Parents Teachers Associations in these schools are not strong enough to sponsor and fund school activities. They depend on government allocation. Students from lower socio-economic backgrounds should be given extra allocation to upgrade the library services since some of them might not have a convenient learning environment at home. Thus, they have to depend on the library facilities and other school facilities for quality education. Thus, these students should be given equality of opportunity to seek quality education.

The number of teachers is also an important determinant of financial adequacy for counselling and other recurring expenditures. Schools with fewer teachers often encounter financial inadequacy and often have less funding for recurring expenditures such as utilities. Thus, additional funding is needed for these schools so that they can operate efficiently.

Fully funded or partially funded Tamil schools also determine the financial adequacy for recurring expenditures. Partially funded Tamil schools often face financial inadequacy. Thus, these schools need to be provided with additional funding so that they can upgrade the facilities and are able to cover infrastructure and recurring expenses.

Therefore, the school funding formulas for Tamil schools need to incorporate some other factors such as the average family income. This is consistent with the previous studies on school funding in the United States. The school funding formula in United States is adjusted for the number of students receiving free lunch, the number of Hispanic students and others. Thus, the policy makers in Malaysia need to take into consideration the necessary adjustments for the school funding formula.

\section{REFERENCES}

A. Ghani, M. F., Mohd Razi, N., \& Siraj S. (2013). Implementing a type of financial managements in Malaysian public schools: An initial study. Global Business and Economics Research Journal, 2(2), 29-51.

Abu Bakar, M. (2010). The implementation of financial management in PTJ secondary schools. (Pelaksanaan pengurusan kewangan sekolah menengah bertaraf Pusat Tanggungjawab (PTj) di Malaysia). Universiti Malaya, Kuala Lumpur.. Retrieved from: http://studentsrepo.um.edu.my/3270/

Abu Bakar, Z. \& Haji Buang, I. (2010). Is it a success or failure when we view from strategic management process? (Suatu kegagalan atau kejayaan jika dilihat dari sudut proses pengurusan strategic). Universiti Teknologi Malaysia, Skudai. Retrieved from: http://eprints.utm.my/11273/

Abu Bakar, Z. \& Haridas, D. (2011). Factors that determine students' achievement in under enrolled National Type Tamil Schools. (Faktor - faktor yang mempengaruhi pencapaian akademik di Sekolah Jenis kebangsaan (Tamil) yang berstatus sekolah kurang murid (SKM) di Daerah Kota Tinggi, Johor). Universiti Teknologi Malaysia, Skudai. 
Ahmad, Andriani, Lokman Mohd. Tahir, \& Bambang Sumintono. (2013). The analysis of challenges in the school operational aid in Indonesia: Case study in National School Makassar Province, Southern Sulawesi. (Analisis cabaran bantuan operasi sekolah di Indonesia: Kajian kes di SMP Kebangsaan Makassar Provinsi Sulawesi Selatan, Indonesia). Working paper presented in 2nd International Seminar on Quality and Affordable Education, 324-336. Retrieved from http://educ.utm.my/wp-content/uploads/2013/11/45.pdf

Ahmad, Z.A. (2002). Module for Guidance and Counselling. (Modul Bimbingan dan Kaunseling). University Terbuka Malaysia.

Akmaliah, Z. (2001). Educational Administration. (Pentadbiran pendidikan). Kuala Lumpur, Malaysia: Fajar Bakti. Retrieved from http://www.worldcat.org/title/pentadbiran-pendidikan/oclc/420758824

Anderson, L., Briggs, A. R., \& Burton, N. (2001). Managing finance, resources and stakeholders in education. London: Paul Chapman.

Baharin, S., \& Abdul Kadir, S. (2013). The need for teacher training in School Financial Management (Keperluan Latihan Guru Dalam Pengurusan Kewangan Sekolah). Seminar Pasca Siswazah Dalam Pendidikan. Kementerian Pendidikan Malaysia, 477-480. Retrieved from: http://www.greduc2013.upm.edu.my/PDF\%20Files/Greduc069\%20Suriyati\%20bt\%20Baharin.pdf

Baharin, S., \& Abdul Kadir, S. (2013). Teacher Competency in school financial management. (Kompentensi guru dalam pengurusan kewangan sekolah). Seminar Pasca Siswazah Dalam Pendidikan. Kementerian Pendidikan Malaysia, 106-110. Retrieved from: http://www.greduc2013.upm.edu.my/PDF\%20Files/Greduc016\%20Suriyati\%20Baharin.pdf

Bogdan, R. C., \& Biklen, S. K. (2003). Qualitative research for education: An introduction to theories and methods (4th ed., pp.110-120). New York, NY: Pearson.

Bruce, J. B., \& David, C. B. (2002). What does the evidence say about unequal school funding and its effects? $A$ research synthesis / Unequal school funding in the United States. 59(8), 48-59.

Cooper, D. R., \& Schindler, P. S. (2006). Business research methods (9th ed.). Boston: MA: McGrawHill/Irwin.

Cresswell, J. W. (2005). Educational research: Planning, conducting and evaluating quantitative and qualitative research (3rd ed.). Englewood Cliffs, NJ: Pearson Merril Prentice Hall.

Hanushek, E. A. (2010). Education production functions: Developed country evidence.In P. Peterson, E. Baker \& B. McGaw (Eds.), International Encyclopedia of education (Vol. 2, pp. 407-411). Oxford: Elsevier Ltd.

Harrington, M. (2011). Australian Government funding for schools explained. Social Policy section. Retrieved from: http://www.aph.gov.au/binaries/library/pubs/bn/sp/schoolsfunding.pdf

Heather Rose, \& Margaret Weston. (2013). Weston California school district revenue and student poverty. Moving toward a weighted pupil funding formula. Public Policy Institute of California, San Francisco, California. Retrieved from: http://www.ppic.org/content/pubs/report/R_213HRR.pdf

Hedges, L. V., Laine, R. D., \& Greenwald, R. (1994). Does money matter? A meta-analysis of studies of the effects of differential school inputs on student outcomes. Educational Researcher, 23(3), 5-14. 


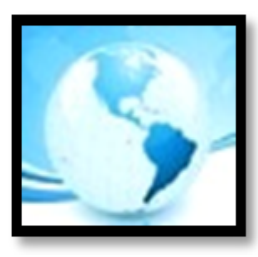

Hosmer, D. W., \& Lemeshow S. (1989). Applied logistic regression. New York, NY: Wiley.

Hosmer, D. W., Lemeshow S., \& Sturdivant, R. X. (2013). Applied logistic regression (3 ${ }^{\text {rd }}$ ed.). New York, NY: Wiley.

Hussian, A. H., \& Mohd Tahir, L. (2012). The practices of school finance among headmasters. (Amalan pengurusan kewangan sekolah guru besar sekolah-sekolah kebangsaan). (Tesis yang tidak diterbitkan, Universiti Teknologi Malaysia).

Idris. N. (2010). Research in Education. (Penyelidikan dalam pendidikan) (Edisi ke-2). Kuala Lumpur, Malaysia. McGraw- Hill Education.

Johari Hassan \& Juwairiah Arifin. (2011). Development of evaluation instrument to assess the CDROM software for interactive physics subjects for national schools. (Pembinaan instrument penilaian untuk menilai perisian CDROM interaktif matapelajaran Fizik Sekolah Kebangsaan). Penerbit Universiti Teknologi Malaysia. Skudai.

Johari, T. (2002). Work conditions, parenting styles and children's school achievement. (Unpublished Ph.D dissertation, University of Sydney).

Johnstone, D. B. (2004). The economics and politics of cost sharing in higher education: Comparative perspectives. Economics of Education Review, 23 (4), 403-410. Retrieved from: http://www.sciencedirect.com/science/article/pii/S0272775703001171

Kenayathulla, H. B. \& Ibrahim, M. S. (2013). Adequacy approach in school finance. Malaysian Online Journal of Education Management (MOJEM), 1(1), 1-19.

Kenayathulla, H. B. (2014). Future trends in the management of school finance: A documentary analysis. Malaysian Online Journal of Eduacation Management (MOJEM),2(4), 89-110. Retrieved from: http://mojem.um.edu.my/filebank/published_article/6811/Volume\%202\%284\%29-6i.pdf

Kenayathulla, H. B. (2015). Ethical issues in the Malaysian education system. Educational Philosophy and Theory, $47(5), 440-454$.

Kling, J. R., Liebman, J. B., \& Katz, L.F. (2007). Experimental analysis of neighborhood effects. Journal of the Econometric Society, 75(1), 83-119.

Krejcie, R., \& Morgan, D. (1970). Determining sample size for research activities. Educational and Psychology Measurement, 30(3), 607-610.

Palaniappan, A.K. (2007). SPSS for research methodology. (SPSS untuk penyelidikan pendidikan). Selangor, Malaysia: Scholar Press.

Marzuki, S. (2005). Managing and financing education in Kuala Lumpur, Malaysia. (Mengurus dan membiayai pendidikan di Malaysia). Kuala Lumpur, Malaysia: PTS Professional.

Marzuki, S. (2005). Financial Management in Primary and Secondary Schools in Malaysia: Issues, Problems and Starategies to overcome. (Pengurusan kewangan di Sekolah Rendah Dan Menengah Di Malaysia: Isu, Masalah Dan Cadangan Untuk Mengatasinya). Masalah Pendidikan, 143-152. 


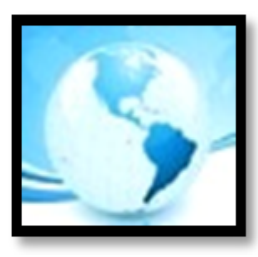

Marzuki, S. (2008). Financial Education Polices. (Dasar kewangan pendidikan). Kuala Lumpur, Malaysia: PTS Professionl.

Mat Saad, A., Nik Yusoff, N. M. R. \& Mohammad Yassin, R. (2011). Evaluation of Facilities for Learning, Financial Allocation and Inhouse training for Islamic course in Malaysian Politechnics. (Penilaian Kemudahan Pembelajaran, Peruntukan Kewangan dan Kursus dalam Perkhidmatan bagi Kursus Pendidikan Islam di Politeknik Malaysia). Journal of Islamic and Arabic Education, 3(1), 123-134.

Ministry of Education, Malaysia (MOE). (2013). Division for primary schools.

Ministry of Education, Malaysia (MOE). (2012). Finance Circulars. Bilangan 8 Tahun 2012 - Garis Panduan Pengurusan Kewangan (Peruntukan Bantuan Persekolahan ke Sekolah Berdasarkan Per Kapita dan Enrolmen Murid). Number 8 Year 2012.

Ministry of Education and Research Sweden. (2008). Funding of the Swedish school system.Retrieved from: http://www.swedenabroad.com/SelectlmageX/165193/Funding-the-swedish-school-system080403\%5B1\%5D.pdf

Ministry of Finance, Malaysia (MOF). (2015). Budget 2015. (Bajet 2015).

Mohamed, N. (2010). Parents' Commitment through PIBG in helping students' academic achievement. (Komitmen Ibubapa Menerusi PIBG Dalam Membantu Pencapaian Akademik Pelajar). Universiti Tun Hussein Onn Malaysia.

Nor Eazrin, Z. (2004). Factors that determine form four students' achievement in secondary schools in Bentong (Faktor yang mempengaruhi pencapaian akademik pelajar tingkatan empat di sebuah sekolah menengah di Bentong, Pahang). (Masters thesis, Universiti Malaya, Kuala Lumpur).

Pallant, J. (2001). SPSS survival manual: A step by step guide to data analysis using SPSS for windows (Version 10). Buckingham: Open University Press.

Parcel, T., \& Dufur, M. (2001). Capital at Home and at School: Effects on Student Achievement. Social Forces, 79(3), 881-911. Retrieved from http://www.jstor.org/stable/2675612

Pigott, T. D., Williams, R. T., Polanin, J. R., \& Wu-Bohanon, M. J. (2012). Predicting student achievement with the education production-function and per-pupil expenditure: Synthesizing regression models from 1968-1994. Retrieved from https://www.sree.org/conferences/2012s/program/downloads/abstracts/457.pdf

Rawls, J. (2009). A theory of justice: Revised edition. Harvard university press.

Ramloo, S. (2000). School Financial Management: Case studies in National Type Tamil and Chinese Schools in Rawang, Gombak District. (Pengurusan kewangan sekolah: Satu kajian kes di SRJK (T) dan SRJK (C) di Rawang (daerah Gombak) Selangor). Universiti Malaya, Kuala Lumpur.

Rengasamy, D. (2007). The relations of academic climate for National Type Tamil school students. (Hubungan Iklim Akademik Murid Sekolah Jenis Kebangsaan Tamil). 


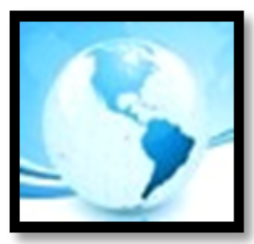

\section{MALAYSIAN ONLINE JOURNAL OF EDUCATIONAL MANAGEMENT (MOJEM)}

Siraj, S., A. Ghani, M.F. \& Mohd Razi, N. (2008). Equity issues in education financing in Malaysia: Other alternativesfor future. Isu prinsip ekuiti dalam pembiayaan pendidikan di Malaysia: Alternatif lain berdasarkan masa depan. Universiti Malaya, Kuala Lumpur.

Tanner, C. K., \& Lackney, J. A. (2006). Educational facilities planning: Leadership, architecture, and management. Pearson.

Uma. S. (2003). Research Methods for business (4th ed.). John Wiley and Sons

Vasquez, H. J., Williams, A., \& Jez, S. (2010). Inputs and student achievement: An analysis of Latina/o-serving urban elementary schools. Association of Mexican American Educators Journal, 10(1), 48-58.

Yee, P. L. (2005). The relationship for family factors and counselling supervision activities for students' academic achievement: Case study. (Perkaitan antara faktor-faktor keluarga dengan aktiviti-aktiviti bimbingan kaunseling terhadap pencapaian akademik pelajar: Satu kajian kes. Universiti Malaysia Sarawak). 